\title{
Etik og kommunikation
}

\section{Af Uwe Geist}

\begin{abstract}
"Det er ikke helt tilfaldigt, at etik og PR ekspanderer voldsomt i B0ernes Europa, og PR nermer sig etikken. Begge dele er affadt af dybtgaiende forandringer i liusbetingelserne, som er beskrevet mange steder. Forurening, globalisering, polarisering mellem rig og fattig, genmanipulation og informationseksplosion er de gennemgåande motiver og et truende kaos det gennemgäende tema." Det er på den baggrund, at Uwe Geist, der er ansat på Roskilde Universitetscenters Dansk/PR-uddannelse, $i$ artiklen prover at komme bagom et modeord, som $i$ de senere air har herget bàde samfundet $i$ almindelighed og PR-branchen i sardeleshed. I artiklen setter han forst begrebet 'etik' op imod beslegtede begreber som 'moral', 'hoflighed' og 'ret'. Dernest diskuterer han etikkens nodvendighed, på den ene side inden for Habermas'teori om kommunikativ handlen og diskurs, livsverden og systemverden, hwor etik ikke handler om faste normer for godt og ondt, men om gensidigheden som grundnorm; pả den anden side inden for Luhmanns systemteori, hror gensidighed ganske vist er funktions- og effektivitetsorienteret, men ikke kan undvare mekanismen og ressourcen 'tillid'. Fordi artiklen omhyggeligt forklarer de centrale begreber, den diskuterer, kan den både fungere begrebsintroducerende for lesere uden omfattende forudsetninger pa feltet, og begrebsafklarende for mere indviede lesere.
\end{abstract}

Mediekultur nr. 20 (1993) handler om Public Relations (PR). PR arbejder med kommunikation, organisation, ledelse og strategilagning, og dets opgave er forst og fremmest at tage sig af virksomhedens - organisationens, institutionens - image. PR har til op i 70 'erne spillet en ret underordnet rolle i Europa. Siden da har det imidlertid udviklet sig med rivende fart. Det er blevet et stort og seriost fag.

Det mest interessante ved denne udvikling af PR - og det som artiklerne i Mediekulturs temanummer derfor også handler mest om - er at etik, social ansvarlighed og demokrati sattes i centrum (Grunig, s.12-13, og Hojberg, s.20), og at PR i stigende grad opfattes som dialog, diskurs, gensidig symmetrisk kommunikation (Heltoft, s. 26, og Nielsen, s. 29). Udviklingen er interessant, fordi kombinationen af okonomi og etik, af lonsomhed og social ansvarlighed, af effektivitet og dialog er overraskende - hvis den da ikke ligefrem er mistankelig.

At kombinationen okonomi og etik er overraskende, betyder ikke at forretningslivet stort set må stemples som umoralsk. Ud over de okonomiske lovmassigheder og de juridiske reguleringer af omrâdet, har der ogsă pâ det okonomiske område altid eksisteret spilleregler, en god forretningsmoral, som det er klogt at følge og som brancherne bruger til at holde en vis selvjustits.

Disse regler bliver for tiden i mange virksomheder, brancheforeninger og organisationer skrevet ned som etiske retningslinjer eller koder. Og det er også godt nok. Men det, der her er tale om, er adfardsreguleringer inden for den økonomiske lonsomheds rammer. Okonomiens primat bliver ikke anfagtet.

Interessant og overraskende bliver det derimod, når etiske overvejelser skal komme ind som afgerende parametre i økonomiske beslutninger, dvs. som den overordnede ramme. Og det er det, der i hvert fald er lagt op til med det såkaldte 'etiske regnskab' - hvor de to sferer etik og økonomi allerede i navnet eksplicit, provokerende og praktiskkonkret bliver koblet.

Sparekassen Nordjylland var den forste virksomhed, der i samarbejde med Handelsskolen i Kobenhavn i 1990 offentliggjorde et săkaldt 'etisk regnskab' (Morsing, 1991). Ud over sit økonomiske årsregnskab aflagde banken her regnskab over hvordan man havde det med de immaterielle vardier: med åbenhed, udvikling, tolerance, tryghed, 
trivsel og tilfredshed; hvilken art af vardiorientering man havde diskuteret og var blevet enig on havde opnået konsensus om - med nogleinteressenterne: de ansatte, kunderne og lokalsamfundet, og hvilken grad af livskvalitet man havde kunnet byde dem.

Selv om det (formodentlig) ikke var tankt som PR, så passede det som fod i hose til moderne dialogisk PR, der opfatter sig selv som koblingsleddet mellem virksomheden og omverdenen, som dem der skal formidle en gensidig tilpasning og ikke mindst som dem der skal formidle mellem de forskellige rationaler, virksomheden og interessenterne tanker $\mathrm{i}$ - som nu økonomi med vardien profit, og etik med vardier som et rent miljo, et menneskevardigt liv og social retferdighed.

På den måde cr det etiske regnskab faktisk et stykke dialogisk PR-arbejde. Det er i hvert fald et glimrende eksempel på et forsøg på at realisere de idealer som ogsâ dialogisk PR stiller op: en formidling af sfarer, der hver isar kun er dele af livets totalitet, men som under udviklingen af det moderne samfund er drevet fra hinanden og har losrevet sig fra hinanden.

\section{Det moderne projekt}

At cn sammenblanding af okonomi og etik - som mange vil kalde det ctiske regnskab - er overraskende for os, skyldes forst og fremmest at vi i vores moderne borgerlig-demokratiske samfund er vant til at tanke økonomi og etik adskilt. Okonomi hører hjemme på markeder og i produktionen, i socialsferen, og har sit eget medium - penge - og sine egne lovmassigheder. Etik hører hjemme i intimsfaren, er et anliggende for det enkelte menneskets samvittighed, realiscrer sig i kerlighed og folger helt andre baner end økonomiske overvejelser.

Men også det etiske regnskabs og dialogisk PR's kobling af økonomi og etik stär i gxild til den samme 'modeme' tankning, dvs. til de tanker og ideer som blev formuleret i forbindelse med oplysningstiden op til de store borgerlige revolutioner i 1800-tallet, og som i efterkrigstiden i forbindelse med de mere og mere massive legitimationsproblemer, som de vestlige demokratier lob ind i, blev reformuleret forst og fremmest af Habermas.

Det var modernitetens store projekt og vision både at skille og at koble de to størrelser. De store omvaltninger hen imod borgerlig-demokratiske samfund som begyndte i slutningen af det 17 . ărhundrede i Europa, sigtede både indad og udad.
Psykologi og politisk okonomi blev de centrale nye borgerlige videnskaber (Habermas 1962:44). Mennesket skulle befries som et selvstandigt trenkende og folende - et dannet - individ, og okonomien skulle befries som en uindskranket produktivkraft. Det skulle forega i hver sin sfare, men i et forudsætningsforhold, ikke uafhangigt af hinanden.

Mennesket skulle i intimsfaren - i et frivilligt og uegennyttigt, men bevidst karlighedsforhold - blive formet til et individ. Det skulle garantere dets grundlaggende anstandige adfærd også i den økonomiske konkurrence senere $i$ produktionslivet og på markedet (samme, 64).

Det er ikke underligt, at det samme ideal om en gensidig og indre afhrengighed af humanisme og forretning dukker op i 1990 'ernes senmodernitet: i det etiske regnskab som et forsøg på at 'gøre etikken praktisk anvendelig som falles verdihorisont og styringsredskab i virksomheden, helt i tråd med at etik også kaldes for praktisk fornuft' (Pruzan og Thyssen 1989:173). Karakteristisk for moderniteten er således en overgribende rationalitet eller fornuft - spæendende også over etik og okonomi.

I modernitetens tidlige revolutionæere faser var det cn optimistisk tro på, at denne fornuft automatisk ville satte sig igennem over for de specielle rationalitetsformer i livets forskellige omrader, barc mennesket kunne handle frit og selvstændigt bäde $\mathrm{i}$ intimsferen, pâ markedet og i virksomheden og i den politiske offentlighed. For så ville den cnkelte $\mathrm{i}$ intimsfaren - $\mathrm{i}$ familiens frivillige og uegennyttige kxrlighedsforhold - blive dannet il menneske, til individ. Det ville give ham selvsikkerhed og styrke til i konkurrence og i samarbejde med andre at bygge en forretning op. Og begge dele tilsammen ville give ham indsigt og integritet nok til at kumne være med til at diskutere og afgore frllesskabets anliggender.

Den sene reformulering af moderniteten i 1960 'erne hos Habermas derimod er snarere gennemsyret af en pessimistisk erkendelse af, at detikke gik som det skulle. At en enkelt rationalitet den okonomiske - havde faet lov til at dominere de andre, og at de borgerlig-parlamentariske samfund derfor er havnet i legitimationskriser, hvor hverken de politiske og okonomiske dispositioner eller livet i familien langere er underlagt og gennemsyret af en overgribende kritisk fornuft. Men visionen om en overgribende formuft er der stadig - en fornuft som det gelder om at genetablere.

På dette punkt skiller modernitet og postmoder- 
nitet afgørende. Postmoderniteten er blevet skeptisk over for modernitetens visioner. Forst og fremmest er man blevet skeptisk over for ideen om at se den endelige forløsning for alt ondt i en varig fornuftig-praktisk kobling af modsatninger.

\begin{abstract}
Moralske anliggender kan ikke blive 'løst'og menneskehedens moralske liv kan ikke blive garanteret ved beregning og lovgivning. Moralitet er ikke sikker i formuftens hander... . Fornuft kan ikke hjalpe det moralske selv uden at berøve selvet det som gor det moralsk: denne ubegrundede, ikke-rationelle, ikke diskuterbare, ikke undskyldelige og ikke kalkulerbare trang til at rakke ud mod den anden, at kærtegne, at vare til for, at leve for, hvad der end måtte ske. Fornuft handler om at traffe de rigtige beslutninger, mens moralsk ansvarlighed går forud for alle overvejelser over beslutninger og ikke har noget at gore med - og ikke skal have noget at gore med - nogen form for logik som ville tillade en afprovning afen handling som korrekt.

(Bauman 1993:247f)
\end{abstract}

Postmoderniteten afskriver modernitetens universalisme, den overgribende rationalitet som urcalistisk og som farlig, og pointerer forskellen, forskelligheden og individualiteten. Men tilbage til en bred forståelse af etik.

\section{Logos, pathos og ethos}

Hvad forbinder PR og etik? Det er forst $o g$ fremmest PR's retorik: Den er praget af ethos-appellen (Jorgensen og Onsberg 1987). Forskellen bliver tydelig, når man sammenligner PR med marketing eller informationsformidling - to andre kommunikationsfunktioner som ligger mere eller mindre tat op ad PR og i praksis ofte integreres.

Lidt skematisk sat op, så er den dominerende appelform for informationsformidling - mest rendyrket $i$ administrativ sammenhang og f.eks. gennem regeringens talsmand - logos-appellen. Informationsformidlingen er koncentreret om sagen, dens stil derfor ofte udpreget saglig.

Marketings dominerende appelform er snarere pathos-appellen. Det grelder f.eks. udpraget for reklamen, som skal påvirke modtageren, forholdsvis hurtigt vakke forholdsvis kraftige emotionelle reaktioner og aktualisere nogle behov som inden for en ret overskuelig fremtid skal drive modtageren til handling.

PR er som sagt karakteriseret ved den tredje appelform: ethos-appellen. PR skal 'søge at opnå for- ståelse, sympati og stotte i de kredse af offentligheden, de har eller vil fia kontakt med' (fra Dansk Public Relations Foreningens definition af public rclations. I: Blach 1989:355). Det er ikke den hurtige reaktion PR vil presse frem; der skal bygges op og vedligeholdes nogle rimeligt konstante og stabile indstillinger og forventninger, som modtageren kan orientere sig ved og handle ud fra. Og det sker forst og frcmmest ved en selvfremstilling som man prover at relatere til modtagerens selvopfattelse.

PR er i hoj grad praget af selvfremstillingens retorik. Og den ethos, de karaktertrak, det sindelag, man påberåber sig, er ofte meget moralsk. Det typiske er således at der i denne sammenhaeng argumen-

\section{Logos, ethos og pathos}

Begreberne logos, ethos og pathos stammer fra den antikke retorik. Her bliver de brugt til at karakterisere tre forskellige måder at argumentere på: Logos karakteriserer den måde at argumentere på hvor man koncentrerer sig om sagen, dvs, prover at vaere saglig, upartisk, klar og logisk og derved at appellere nil forstanden. Det kaldes ogsa for 'docere - at fremlagge sagen som en rakke kendsgerninger som med logisk tvingende nødvendighed forer frem til bestemte slutninger.

Hvor logos appellerer til publikums intellekt, appellerer ethos og pathos forst og fremmest til folelseme. Ethos karakteriserer den måde at argumentere $\mathrm{p}^{a}$, hyor den talende prover at fá publikums sympati, agtelse og tillid og derved sogger al overbevise det. Den talende argumenterer med sine cgne (eller en anden autoritets) positive karakteregenskabet; såsom kompetence, acrlighed og retskaffenhed.

Pathos derimod er koncentreret om pubilkum. Appelformen går ud pả at vakke publikums lidenskaber, hensette det i en bestemt stemning - f.eks. angst, vrede, begejstring eller medlidenhed - således at denne stemning bliver afgorende for, hvad det tror og mener om sagen.

Charlotte Jorgensen/Merete Onbberg: Praktisk argumerituton Alknisk Forlag, Kabenhavn 1987.

Hewneh Lauberg. Hindbuch det Itrarischen Rlietorik, Mar Hieber. Vollay, Munchen 1960. 
teres med afsenderens dyder som kompetence, ansvarlighed, altruisme og lign. (Kjøller 1980).

Det at PR i højere grad er koncentreret om selvfremstillingen, betyder ogsa at modtageren ikke er så presset. Ethos-appellen er ikke bare mere afdampet, den indrommer også modtageren - i hvert fald som en tekstlig gestus - en storre selvstændighed $i$ at danne sig sin egen mening.

Pointen $i$ denne sammenligning er ikke at PR pa grund af ethos-appellen pr. definition er mere rigtig eller sandfardig. Den ene appelform er ikke i sig selv bedre end den anden. De har alle deres idealer. Logos-appellen har sandheden som ideal, pathos-appellen relevansen og ethos-appellen vederhaftigheden. Og de kan alle misbruges i dette ideals navn.

Pointen er i forste omgang den, at PR som type af interaktion via ethos-appellen arbejder med teknikker som signalerer etisk adferd - og selvfolgelig også kan vare det: Man overskrider ikke - som ved pathos-appellen - den andens sikkerhedszone, dvs. respekterer den andens frihed, og man viser -i modsatningen til logos-appellen - hvad man selv mener og hvor man selv står, dvs. viser ansvar for egne handlinger og holdninger.

\section{Etik og moral}

I $50^{\circ}$ erne, i koldkrigsperioden, blev der i den vestlige verden talt meget om moralsk oprustning. I dag, i globaliseringens og FNs tegn, bliver der talt meget om fred og etik. I begge tilfalde er der tale om immaterielle vardier, der er af afgørende betydning for menneskers samliv i samfund. Men i forbindelse med moralsk oprustning var der tale on ganske bestemte vardier i ganske bestemte samfund som var bedre end andre samfund $o g$ andre vardier, og som derfor skulle forsvares mod disse andre værdier. I dag er der i forbindelse med etik derimod snarere tale om indre indstillinger, holdninger og reflcksioner som er alment gyldige og som snarere skal bidrage til at forlige de forskellige lokale moraler (Pruzan 1989).

Etik er afledt af gresk ethos som i ethos-appellen har betydningen: karakter, tæenkemåde. Med til ethos ${ }^{3}$ betydning horer imidlertid også: sxdvane, skik og brug. Det er den betydningsvariant, etik er knyttet til i betydning: leren om skik og brug, om det, der sommer sig.

Og så har ethos endelig en tredje betydningsvariant : hjemstavn, boplads, hjemligt sted - det kendte, det vante, det trygge. Og den er ogsa -lige- som karakter/tankemäde og skik/brug - interes sant i forbindelse med etik. For skik og brug er selvfolgelig hjemstavnens, bopladsens skik og brug. Det er de usynlige tråde som binder en gruppe, et samfund sammen som netop bor, lever, er samme sted.

Betydningsbredden i ordet ethos viser således at begrebet etik - i hvert fald etymologisk - er forankret i det, som i sociologien går under betegnelsen livsverden: den erfaringshorisont hvis 'almene, anonymt konstituerede fortrolige bekendthed' vi altid forudsætter som en selvfolgelighed (Luhmann 1973:22; jvf. oggå Habermas 1981:II.182ff)) og som derfor er gået os i blodet og er blevet en del af os selv - som verden, vores skik og brug, vores tzenkemåde, vores forestillinger om rigtigt og forkert.

Eller som vi vil se senere: Fortrolighed skaber tillid, tillid er grundlæggende for at samfund kan fungere, og tillid er en forudsætning for og en folge af etisk handlen. Etisk handlen er tillidsfuld handlen, der både bygger på og skaber tillid.

Det latinske ord der svarer til ethos, er mos eller mores, som moral er afledt af (Hansen 1992). Moral bruger vi i dag som betegnelse for det bestemte saet af regler som bestemte grupper eller samfund anser for at vaere de rigtige og som de lever efter. Etik derimod er laren om moraler eller moral mere alment, men kan også bruges om sat af principper der ligger bag en eller flere moral(er). Typisk markercr menneskerettighederne således et sat etiske principper.

Ordene moralsk og etisk forholder sig tilsvarende til hinanden. Moralsk betegner bevidst overensstemmelse med en bestemt moral, mens etisk snarere betyder rigtigt i en mere overordnet og almen forstand. Når vi i dag taler om det, vi selv anser for det rigtige og gode, să bruger vi snarere det brede begreb ctik/etisk, der mere går på almene principper, end det snævre moral/moralsk, der mere găr pả konkrete regler.

\section{Hoflighed}

Også hølighed hører med til samme betydningssfare (rigtig/forkert) som moral og etik. Men hvor moral snarere găr i retning af internaliserede vardier og folelsesmassige forankringer (godt/ondt), går høllighed som en mere afsvakket og tilsyneladende mindre forpligtende form i retning af social konvention, dvs. passende/upassende.

Høflighed skal imidlertid ikke undervurderes (jvf. sagen om Kommiswens dagbog!). Ved nær- 


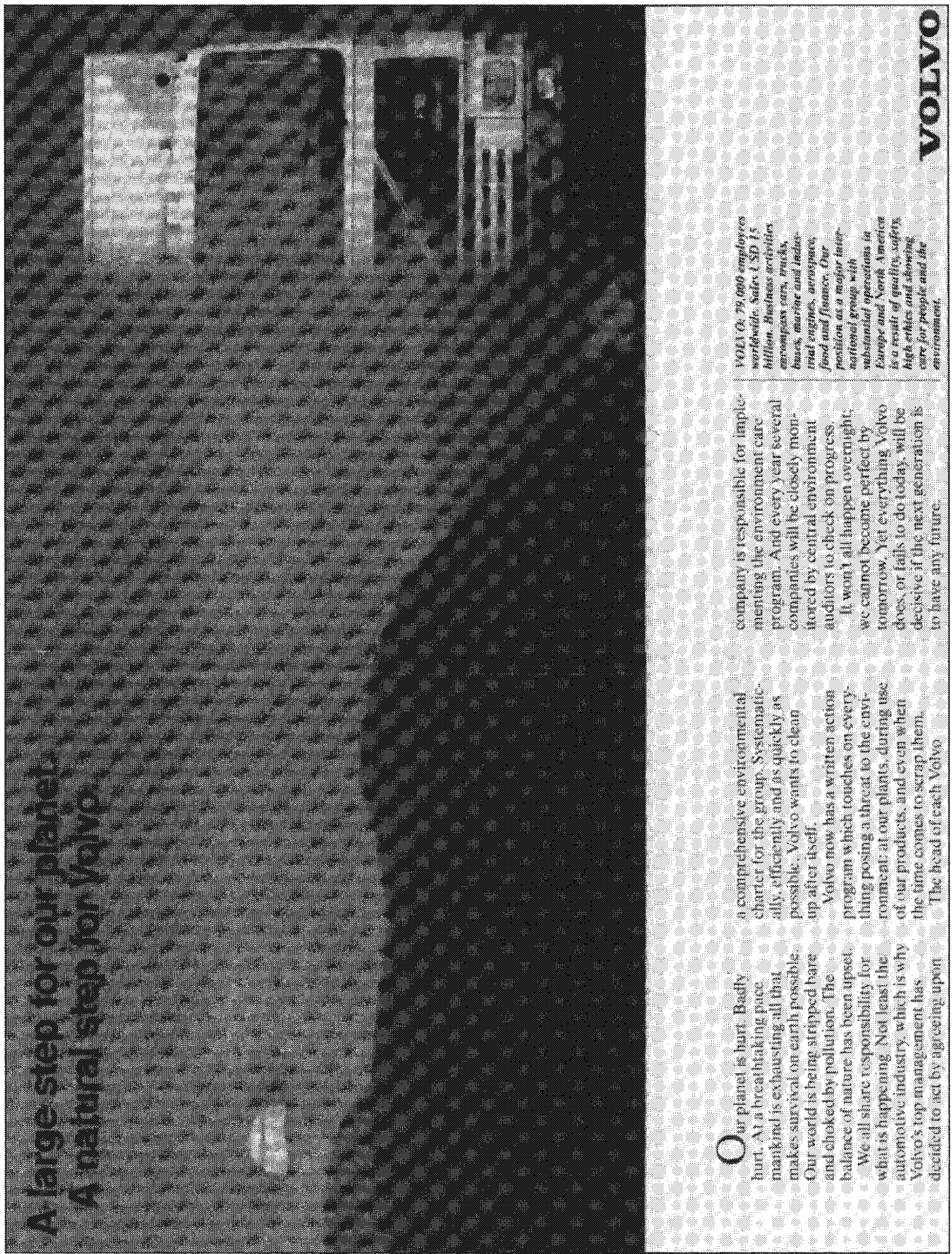

I1990erne har etikken for alvor fundet vej til reklamen, ofte iforbindelse med miljoproblemstillinger. I denne image-reklame forteller Volvo om sin miljopolitik, og beskriver sin forende rolle pä en rekke omradder som sa result of quality, safety, high ethics and showing care for prople and the environmente (Scanorama Magazine 1990). 
mere granskning er det ikke det overfladiske og lidt forlorne fanomen, som det ser ud til at vare, men en vasentlig mekanisme til at undgå, afvarge og bilægge konflikter som potentielle trusler mod det tillidsfulde, vanepregede, forventningstunge dagligdags samliv,

Hoflighed og takt, sådan som Goffman (1992) og Brown/Levinson (1978) forstår det, bruger man til at værne om hinandens offentlige selvimage som ethvert medlem onsker at gøre galdende' (Brown 1978:61), 'det indtryk en person ønsker at give i andres narvar' som led i hans definition af situationen (Goffman 1992:21), eller kort: hans ansigt, 'face' (Brown 1978).

Face, selvfremstilling og lidt bredere definitionen af situationen skal der varnes om, fordi de er afgørende vigtige for en gruppes eller et samfunds fungeren. For social interaktion styres ikke af love, men af forventninger. Social interaktion udvikler sig ved at man knytter an til egne og andres forventninger, går videre med dem, forholder sig til dem. Men forventningerne skal skabes, og det bliver de ved selvfremstilling og definition af situationen, f.eks. når jeg henvender mig til en tilfældigt forbipasserende og sporger hende om vej. Jo merc ensomt der er, jo mere omhyggelig vil jeg være $\mathrm{i}$ min definition af situationen og i min selvfremstilling der uvilkårligt folger med: som fredelig fremmed der er faret vild og ikke vil andet end at komme på rette vej igen. For hvis det ikke lykkes mig, vil hun măske lobe skrigende bort, tilkalde politiet, lade mig arrestere osv.

Derfor stăr der meget på spil ved definitionen af situationen og ved selvfremstillingen. Det, der står på spil, er individernes face, deres omdørmme og deres selvvurdering. Risikocn ved det er at de máske i deres selvfremstilling ikke bliver accepteret eller at de ikke kan opretholde deres selvfremstilling, dvs. de bliver 'afsloret'. Hvis det er tilfeldet, taber de ansigtet, og det er de bange for. Derfor vil de vare tilbojelige til at spille meget forsigtigt og vagt ud.

Men vage udspil giver kun vage forventninger. Interaktionen bliver mere meningsfuld jo tydeligere og mere entydige forventninger der kan udvikles.

Der er således tale om et dilemma: Jo klarere man melder ud, jo mere meningsfuld kan interaktionen blive. Men jo klarere man melder ud, jo storre er også risikoen for, at man bliver afvist og lider nederlag.

Idette dilemma formidler takt og hotlighed. De gor det nemmere at spille ud og de gor det nem- mere at acceptere udspil - ved at gore det nemmere for parterne at bevare ansigt. Og på denne máde skaber de forudsatningen for det vigtigste i grupper eller samfund: meningsfuld interaktion, samarbejde.

Goffman kalder med rette dette forhold for moralsk (Goffman 1992:20). I og med at man varner om hinandens face, accepterer man hinanden som selvstændige individer og indrommer hinanden frirum og selvvæerd. Men på den anden side forpligter man netop på den măde også hinanden på selvfremstillingerne og situationsdefinitionerne. De er jo netop valgt af nogen, der har face, dvs. er noget vard og kan noget selv. Den varste trussel mod ens ansigt er hvis man ikke selv kan holde masken og falder ud af rollen (samme 210). Og når masken holdes, så bliver spil efterhånden til realitet, så identificerer man sig efterhảnden med de normer, som man i første omgang måske kun rimeligt opportunistisk 'forsøger at havde i de andres nærvær' (samme 73).

Jeg vil komme tilbage til det i forbindelse med Luhmann og under stikordet kynisk etik, men vil foreløbig holde fast i den pointe, at takt eller høflighed kan betragtes som en dagligdags mekanisme til at sikre hinanden en vis grad af selvvard og frihed og til at holde en fast $i$ en vis grad af ansvarog săledes altså som etisk.

\section{Ret}

Og endelig hører også ret - ligesom etik, moral og høflighed -- med til betydningssfaren rigtig/forkert. Den dimension, ret fokuserer på, er imidlertid hverken den cksistentielle (godt/ondt) eller den konventionelle (passende/upassende). Det er dimensionen 'det eksplicit koderede og regulerede' (tilladt/forbudt).

Forskellen og sammenhangen mellem etik/moral og lov/ret cr interessant, ikke mindst for en narmere karakteristik af etik. 'Vi kan ikke uden videre antage, at loven udtommer moralen. Loven er altid selv genstand for moralsk granskning og moralsk kritik, og det er i princippet altid et àbent sporgsmålet, om man skal holde loven.' (Callahan 1988:11). Ret og lov er udspaltet fra det etisk-moralske område som en systematisering af skik og brug, som et ekspertsystem, og har til en vis grad selvstandiggjort sig. Habermas taler ligefrem om ret som en 'moralfri zone' (Habermas 1981:I.354). Argumenterer man med loven, argumenterer man inden for et lukket system. Argumenterer man 
med moral eller etik, argumenterer man med mere åbne og mere personligt forpligtende normer.

I forlangelse af det er rettens og lovens ultima ratho sanktionen. I sporgsmål om moral/etik derimod bærer selve handlingen principiel straffen eller belonningen i sig selv, som vi så tit i frustrerede ojeblikke har fået det at vide, eller den er lagt ud i det hinsides.

Lov og moral kan således godt stå i modsætning til hinanden. Men lov og ret forudsatter etik og moral. Lov og ret fungerer kun hensigtsmassigt, hvis der er bevaret en tilbagekobling, hvis loven kan legitimeres etisk. Den skal bakkes op af en retsbevidsthed eller moral. For ret vil aldrig kunne komme til bunds i den utrolig komplekse og tilfældige verden, som den skal regulere. Og jo flere regler man laver, jo flerc huller bliver der mellem reglerne, som Luhmann gør opmarksom på (Luhmann 1987:391). Og jo flere huller der er i loven, jo mere er samfundet afhrengigt af at folk opforer sig anstandigt, ordentligt og etisk - og ikke bare lovlydigt. For det, der mangler i loven, er den indre, personlige accept og forpligtelse, som kun en moral eller etik kan give os som noget der ikke er til at komme udenom.

Tænk bare på sammenhangen mellem skattelovgivningen og skattetænkningen. Enhver skattelovgivning vil ikke bare gøre skattetankningen mulig, men ligefrem animere til skattetankning, dvs. at man inden for lovens rammer bruger alle kneb til at tilgodese egne interesser, også dem der åbenlyst strider mod lovgivningens intentioner. Jo mere avanceret skattesystemet bliver, jo mere sport synes der at gå i skattetænkningen og jo større bliver gevinsterne.

\section{Ekspertisens sejrsgang}

Det er ikke helt tilfaldigt at etik og PR ckspanderer voldsomt i $80^{\prime}$ ernes Europa og PR nærmer sig etikken. Begge dele er affødt af dybtgående forandringer i livsbetingelserne som er beskrevet mange steder (feks. Drucker 1989; Bauman 1993; Giddens 1994). Forurening, globalisering, polarisering mellem rig og fattig, genmanipulation og informationseksplosionen er de gennemgående motiver og et truende kaos det gennemgâende tema.

Centralt står det paradoks at vi kan så meget, vi er blevet så dygtige til mange ting, at det faktisk er for meget og vi ikke kan styre det. Det løber fra os og truer med at slå os ihjel.

Kernen i dette paradoks er modsatningen mel- lem isoleret ekspertviden og en holistisk forståelse af globale sammenhange! Og dens opståen spores tilbage til begyndelsen af den moderne tidsalder. For Habermas er det et afgørende skridt i rationaliseringen af livsverden, for Giddens er det udlejring og for Baumann fragmentation. Ogsă Luhmann kender fanomenet og kalder det for differentiering.

Fænomenet er også på en anden måde paradoksalt, fordi det i reglen er beskrevet som både rummende muligheder for emancipation $o g$ for pervertering. Tydeligst er det måske hos Habermas. For Habermas er modernitetens - oplysningens - store projekt emancipationen af mennesket, dets befrielse til frit at kunne bruge den mest menneskelige $o g$ samtidig den mest effektive af alle menneskets evner: rationel formuft. Moderniteten er fornuftens befrielse for religionens og magtens overherredornme, eller sagt på en anden måde: rationaliseringen, fornuftiggerelsen af de livssammenhange der tidligere blev kontrolleret af magt eller (over-)tro. Rationaliseringen af livsverdenen kunne nu skride mere uhindret frem. De enkelte områder kunne nu hver især udforskes og udvikles helt i overensstemmelse med deres iboende rationale, fri for uvedkommende, feks. religiose, begransninger.

Det er et gode, en aflastning, en forbedring af livsvilkårcne. Men det har samtidig vist sig at være uhyre farligt. For udviklingen accellererer, frit og ukontrolleret, i en sădan grad at de losslupne systemimperativer sprenger fatteevnen af livsverdenen, som de prover at instrumentalisere" (Habermas 1981: II.232f).

Lagen kunne nu ganske vist frit undersøge kroppen, kroppens funktioner og fejlfunktioner og kunne derved skaffe en masse viden, som gjorde dagliglivet nemmere og bedre. Men medicinens udvikling accellererede i sin bane, på egne præmisser, og er ved at ende $i$ ct apparat, som măske odelagger lige så meget livskvalitet som det skaber.

Teknikeren kunne nu - uden hensyn til andetudvikle mere og mere effektive metoder til f.eks. at udvinde råstoffer. Indtil denne i starten meget nyttige proces stodte på sine egne grænser, og de destruktive sideeffekter af den, som f.eks. forurening og opvarmning af kloden, blev mere og mere tydelige og dominerende.

De isolerede ekspertområder begyndte således at sprange livsverdenens rammer og ødelagge den, som de egentlig skulle tjene. 


\section{System- og livsverden}

Habermas beskriver samfundet som en dobbelthed bestäende af hvad han kalder livsverden og systemverden. Begge begreber har en lang historie, hiver for sig.

Livsverden er et centralt hermeneutisk begreb. For hermeneutikken bygger forstảelse altid pä en tidligere eller en mere grundlaggende forståelse. Der er altid givet en forstảelse, som vi som medlemmer af et samfund og brugere af et sprog fra vores tidligste levetid er vokset ind i. Denne forståalse er săledes ogsả en falles og i sidste ende en umiddelbart given og derfor helt uproblematisk forstäelse. Det er demne forstäelse, vi lever ud fra og lever i. Det er den, der har skabt vores livsverden.

Systemteori betragter det, der er i verden, som systemer. Bt system er en afgranset helhed som indadtil er struktureret pả en bestemt måde. Alt uden for det enkelte system er systemets omverden, som det er mere eller mindre ibent eller lukket overfor, og som det skal prove at overleve i og regulere sig selv $i$ forhold til.

Det systembegreb, som er interessant $i$ denne sammenhang, cr et funktionalistisk systembegreb anvendt pá sociale sammenhange (Parsons, Luhmamn).

For funktionalistisk systemtacnkning er det ikkc tolkning, forstáclse, normer og intentioner, som memnesket konstruercr sin verden med. Her udvikler det sociale system selv mallorienterede mekanismer for at prove at sikre sin funktion og dermed sin overlevelse. Og tolkning, forstâelse, normer og intentioner er underkastet disse mekanismer.

Habermas kobler de to begreber. Livsverden er også for ham altid umiddelbart givet som horisont og grundlag for en falles og uproblematisk forstąelse En sådan forstäelse er uundvatlig for interaktion som sikrce mennesket sin overlevelsc. Det er sảledes meget vigtigt at der skabes og opretholdes en felles, uproblematisk forstå else 1 et samfund. - Det sker gennem sproglig kommunikation og efter en kommunikativ logik som kun anerkender det som gyldigt, som man efter en grundig diskussion frivilligt anerkender og tilslutter sig. Og det sker i livsverden, i en sfare af gensidig kerlighed (familien) og en sfere af gensidig respekt (offentligheden).

Men livet har ikke bare en kulturel, men ogsa en materiel side. Det er her systemer kommer ind $i$ billedet. Det er strukturer, der udvikler sig og som gor det nemmere at organisere sig og at skafe sig og producere livsnodvendighedeme. Der er for det forste produktionsfiaren og for det andet statsapparatet. Disse sfarer korer ikke efter en kommunikativ, men efter en funktionel rationalitet. Deres dominerende medier er ikke sproglig kommunikation, men penge og magt.

Livsverden er for Habermas den forudsatte sfere, systemverden den aftedte, afhangige. Problenet er imidlertid at systemverden $\mathrm{i}$. lobet af den moderne samfundsudvikling har ekspanderet sá meget, at den derved 'koloniserer' livsverden, undertrykker den, tranger den tilbage, forhindrer den $i$ at fungere efter dens egen logik.

Det forer til manglende reproduktion aflivsverdensressourcerne (mening, solidaritet og identitet) som også systemverdenen er afhangíg af, og derved patologier, sygclige tilstande, for samfindet.

Herrik Kaare Nielsen: Demokrati i bevzegelse: Arhus, Arthus University Press 1991.

Walter Reese-Scháfer, Jügen Habermas. Campus Verlag, Frankfurt M, New York 1994.

Jurgen Habermas/Niklas Lulmann: Theorie der Gesellschaft oder Sozialtedmologie: Suhrkamp Verlag FrankfurtM 1971.

Altred Schütz/Thomas Luckmann: Strukturen der Lebenswelt, Frankfurt/Main, Suhrkanp Verlag 1979.
Faren ligger ikke i rationaliseringen, men i frakoblingen af et globalt perspektiv, i fragmenteringen af livsverdenen, således at de enkelte omrăder ikke afbalanceres mod hinanden, men i konkurrence med hinanden odelagger den helhed, som de er afhangige af. Processen er altodelaggende, fordi systemverdeneme, de enkelte fragmenterede ekspertomrảder $i$ virkeligheden til trods for deres magt $o g$ valde ikke kan eksistere i kraft af sig selv. De er afhangige af den livsverden, som de er ved at drane for liv.

Således er f.eks. retssystemet afhængigt af etikkens indre rast 1 individet, af en bevidsthed om rimelighed og retfardighed, der eksisterer for og 
uafhengigt af retssystemet og som retsystemet oprindeligt er udsprunget af. Retssystemet alene kan ikke klare sig.

De moderne industrisamfund synes at vare nået til det punkt, hvor denne paradoksi eller ironi - at systemerne der skulle aflaste livsverdenen, er ved at ødelagge den - synes at blive ubarlig.

Verden er blevet en anden. Måske ikke så meget fordi forurening, krig og sult har nået nye, uanede hojder, Måske mere fordi livsverdenen synes at begynde at slå igen og synes at have held med at havde sig? Vi er så vant til paradokset, at det omvendte begynder at forekomme os paradoksalt: at psykiske energier kan udrette mere end piller og operationer, at folkehare kan bescjre avancerede krigsmaskiner, at civil modstand kan knække terrorregimer.

Verden er måske ved at blive en anden fordi vi er kommet ud i en tilstand hvor kaos - 'støj, den eneste mulige kilde til nye monstre ${ }^{3}$ (Bateson 1972) - er ved at danne paradigme og livsverdenen derfor fär mulighed til at mobilisere.

Genkomsten af etikken - en typisk livsverdensressource - kunne tolkes i den retning. Udviklingen af dialogisk eller 'symmetrisk, tovejs-' PR også.

\section{Fra bevidsthed till sprog}

Den moralsk-etiske dimension har fra starten spillet en stor rolle inden for tankning omkring moderniteten. Adam Smith, grundlæggeren af den moderne liberalistiske nationalokonomi, var også moralfilosof, og Kant har ikke kun skrevet $\mathbf{K}$ ritik der reinen Vernunft, men ogsa Kritik der praktischenVernunf, en praktisk filosofi, en handlingens filosofi, og dvs. en etik.

Rationalitet skulle fra starten abalanceres med etik, med en etisk forpligtelse, som imidlertid selv skulle tankes rationelt og fornuftigt. Kant formum lerede derfor den săkaldte kategoriske imperativ: 'Du skal kun handle efter den maksime, der er således at du samtidig kunne onske at den blev gjort til en generel lov' (citeret efter Næss 1967:II.299).

Det dybt moderne ved denne etiske grundsxtning er netop, at Kant her ikke udtaler sig om, hvad der substantielt set er moralsk, men giver en formel anvisning på hvordan man selv kan finde frem til eller afgore hvad der er moralsk forsvarligt i en given situation. Det er en rationel procedure han indfører, som man til gengald er forpligtet til at bruge og rette sig efter, Men ikke bare overgangen fra det substantielle til det formale er karakte- ristisk for overgangen til moderne tankning. Også overgangen fra det lokale til det universelle er det.

Alle Menschen werden Brüder' hedder det nu i Schillers An dic Freude.

Etik og gensidighed har altid eksisteret, men forst $0 \mathrm{~g}$ fremmest inden for gruppen, stammen, folket som talte samme sprog. Dem, man ikke kunne tale med, var man tilbojelig til at sla ihjel. Her har den funktion som aggressionskontrollerende gruppeintern moral' (Habermas 1980:36). Men en sådan moral er ikke længere tilstrækkelig, nårverden bliver integreret, horisonten udvides og grupper og folk bliver bragt $i$ kontakt med hinanden som det er typisk for den moderne tidsalder. Sa skal der udvikles en højere form for moralitet, en mere formel og universel etik, som netop kan klare forskelle mellem forskellige moraler, sådan at der kan bestå forskellige former for moral ved siden af hinanden.

Det formelle, det procedurale, og det universelle er det, der peger fremad og som netop stadig er aktuelt i Habermas' kommunikative eller diskursive etik. Men Habermas udskifter den bevidsthedsmassige procedure, som Kant bruger, med en sproglig procedure. Hos Habermas skal man ikke txnke sig til hvordan man bor handle, man skal diskutere sig til det-sammen med andre, i en dialog. Forskellen bliver klar, når man sammenligner den kategoriske imperativ med grundsatningen i Habermas' diskursetik: 'Du skal kun handle efter den maxime, der er således, at du samm tidig kunne onske at den blev gjort til en generel lov' (Kant) og 'Kun de normer kan gøre krav på gyldighed, som alle de som det angâr, som deltagere i en praktisk diskurs kan (eller ville kunne) tilslutte sig' (Habermas 1983:103).

Etikken er således også hos Habermas formelt bestemt, men den udspringer af social interaktion. Den er på en måde selve indbegrebet af interaktion eller samarbejde. Eller lidt anderledes udtrykt: Etik er gensidighed som grundnorm (Apel 1984:83).

\section{Kommunikativ handlen og ideele talesituationer}

For Habermas er sclve den historiske rationaliseringsproces som sagt grundlaggende en befrielsesproces. Rationaliseringen af livsverdenen - det at kumne reflektere formuftigt og kritisk over hvad man går og gør - er befriende ved at sprange 
f.eks. religiøse bindinger og derved give, den enkelte reelle valg. Systemdannelserne, som er en konsekvens af den, er et langt stykke hen ad vejen harmlose systematiseringer og som sådanne aflastningsmekanismer $i$ livsverdenen. Penge er således en udmærket opfindelse, som letter udvekslingen af varer og ydelser enormt. Men når penge bliver målestok for alt, og princippet om at penge skal blive til flere penge bliver det øverste princip, så ader pengesystemet sig så langt ind i den enkeltes livssfare at den enkelte ikke lingere kan administrere den efter eget skon. Når stort set alle situationer og alle valg, som den enkelte vil kunne komme i, er forformet af en begranset okonomisk rationalitet, som vil sætte sig igennem automatisk, så har den enkelte mistet grebet om sit eget liv, så opstår der sygdomstilstande, patologier, i livsverdenen. Det er patologier lige fra individuelle psykopatologier til kollektive normsammenbrud. Og som patologier truer de livsverdenens ressourcer: solidaritet, jeg-identitet og mening (Habcrmas 1981:II.216).

For Habermas er den eneste vej ud af krisen en tilbagevenden til ảben og agte sproglig kommunikation: kommunikativ handlen og diskurs - som grundlaggende er etisk handlen.

I sproget ligger for Habermas kimen til al etik. I det øjeblik man begynder at bruge sproget til det, der er sprogets inderste vasen eller bestemmelse til at ville opnå en gensidig forståelse - begynder man at handle etisk og begynder dermed at genopbygge livsverdenen. Og det er den máde sproget ifig. Habermas i det daglige bliver brugt: som kommunikativ handlen. Og det cr den primare măde at bruge sproget på. Selv den der lyver - der altså ikke selv prover at bruge sproget til at opna en gensidig forståelse - må lade som om han bruger sproget forståclsesorienteret, og bygge på at den anden også gar det. For ellers ville løgnen ikke kunne funw gere som logn, men bare falde til jorden.

I den daglige brug af sproget, i kommunikativ handlen, udveksler deltagerne information, går og formidler erfaringer og styrer og udforer handlinger. Kommunikativ handlen $\mathrm{cr}$ med andre ord vavet ind i de dagligdags aktiviteter som vi klarer dagen og vejen med og som skaffer os mad på bordet. Instrumentel handlen som Habermas kalder det.

Men kommunikativ handlen har en dobbelt struktur. Kun til den ene side er den koblet til handling, der har til formål at klare sig i denne verden. Til den anden side er den koblet til det, Haber-

\section{Diskurs}

Diskurs bliver brugt i en hel rakke forskellige betydninger, lige fra samtale over 'the written or spoken 'product' of the process of text prodiction' til 'ways of structuring areas of knowledge and social practice' (Fairclough). Diskurs er 1 denne artikel brugt i Habermas' forstand, og Habermas bruger det pã en helt speciel måde.

For Habermas er det at fore en diskurs en bestemt maide at kommunikere: at problematiscre og at diskutere et udsagns gyldighed og at fastlixgge normerne for gyldighed. Nâr vi snakker sammen til daglig forudsatter vi i reglen 'naivt' gyldigheden $\mathrm{i}$ det vi siger, og normerne for derne gyldighed; vi forudseetter at vi taler sandt, vederhieftigt og rigtigt med hinanden.

Men bvad er sandt, vxederheftigt og rig. tigt? Kun det som vi er blevet enige om - eller forudsaetter at vi kumne blive enige on. Den slags diskussioner hyor man bliver enig om det-diskurser -er det derfor engang imellem nodvendigt at fore. De er loftet ud af vores daglige snak - vores kommunikative harrdlen, som Habernas kalder det. For med kommunikativ handlen handler vi $i$ denne verdens bredere kontekst og er derfor underlagt den. Den satter forudsetningerne for vores tale Vi forlolger altid nogle mal i verden der ligger ud over selve det at kommunikere og blive enige.

Diskursen er kendetegnet ved at den loftes ud af disse ekstra-kommunikative sammenhange og helt er koncentreret om det sagte: om det er sandt, vederhaftigt og rigfigt, og hvad det $i$ ovrigt er.

Dermed er diskursen loftet ud af denne verden og dens sammenhenge og er ideel. Den ligger som et ideal bag kommunikativ handlen og er som ideal kontrafaktisk - dvs. i en ren form ikke til at finde i virkeligheden.

Norman Fairclough: Discourse and Social Change. Blackwell Pubi., Cambridge 1994 (1993)

Walter Reese-Schäfer, Jürgen Habermas. Campus Verlag Frankfurt/M. New York 1994.

Jürgen Habermas/Niklas Luhmann: Theorie der Gesellschaft oder Sozialtechnologie Suhrkanp Veling, Fankfurt M. 1971. 
mas kalder diskurs. Det ligger latent i kommunikativ handlen at den til ethvert tidspunkt kan løftes ud af de handlingssammenhænge som den er bundet ind i, og overfores til et metaplan, til en diskussion af den kommunikation, man er i gang med til diskurs.

I diskursen drejer det sig så ikke mere om punkterede cykler, havefester, galdsbeviser og hvad vi ellers snakker om i hverdagen. Emnet for diskursen er selve den snak, man er i gang med, og det der diskuteres er om den er sand, arlig og rigtig -de tre universelle krav som man i den lobende dagligdags kommunikation 'i naiv tro' (Habermas 1971a:197) antomatisk går ud fra er opfyldt ( - det fjerde, lidt mindre interessante krav er kravet om korrekthed). Disse krav ligger altid latent $\mathrm{i}$ kommunikativ handlen. Men enhver deltager kan til enhver tid krave dokumentation for og diskussionen af om kommunikationen nu også lever op til dem.

Det etiske ved diskurs er at den enkelte deltager - i pagt med oplysningens emancipatoriske grundidé - på diskursens metaplan er fri. Han er løftet ud af sociale sammenhænge der kan vare bestemt af status og magt, han er kun forpligtet over for rationaliteten som kommer til udtryk i sproget. Ellers er det ik ke nogen diskurs.

For 'diskurs er omgangssproglig kommunikation $\mathrm{i}$ en form, der er befriet fra interaktionens tvangsmekanismer' (samme 199). 'I diskursen er de deltagende udelukkende orienteret imod meningssammenhangenes eksplikation' (samme 200). Diskursen er således alene en 'kooperativ søgen efter sandheden, dvs. en principielt uindskrenket kommunikation, befriet for tvang og udelukkende med forståelse som formăl' (samme 201).

Det kalder Habermas også den ideale talesituation. Den er kendetegnet ved 'den symmetriske fordeling af chancerne for at indtage dialogrollerne og for at udfore (alle slags) talehandlinger ${ }^{3}$ ( $\mathrm{Ha}$ bermas 1971b:139). Den'udelukker systematisk forvrangning af kommunikation', og den varer indtil den har udtomt sig selv og en agte konsensus er nået. Kun sả kan der vare tale om 'det bedre arguments ejendommelige tvanglose tvang' (137) som viser at det kun er rationaliteten der rảder og ikke nogetsomhelst andet.

I ren form er diskursen og den ideale talesituation kontrafaktiske - de findes ikke i virkelighedens verden. Det, der er beskrevet i den ideale talesituation, cr ct ideal som vi orienterer os ved i al kommunikation og som vi bruger som målestok.
Det er den forudsatning vi er nodt til at kommunikere ud fra og også ubevidst gor det. Al kommunikation ville bryde sammen, hvis man ikke som regel på forhånd kunne regne med - og faktisk også naivt gor det - at parterne da stort set er ærlige over for hinanden, taler sandt $\mathrm{g}$ vil overholde normerne. Man kan i langden ikke spille med en, som konsekvent snyder. Man kan ikke tale med en, som hele tiden lyver og bedrager.

Den ideale talesituation er den barende grund for al sproglig kommunikation og kemen i dens etik. Det betyder selvfølgelig ikke, at den altid holder. Men så kan diskursen komme på banen - så kan man, på baggrund af den principielle enighed om de overordnede regler, kontrollere om de bliver opretholdt og checke dem.

\section{Idealitet og realitet}

Den ideale talesituation er altid en anstodssten for tanken, når Habermas' teori bliver prasenteret. Den forekommer at vare totalt urealistisk og derfor uforpligtende og ligegyldig. Hvad skal vi med den năr der ikke er nogen der overholder den? Hvad skal vi med de idealiteter, der i realiteten ikke holder?

Luhmann har kritiseret den udforligt og noje påvist, at den rent faktisk slet ikke kan opfyldes (Luhmann 1971:316f). Nej, det kan den ikke, for den er jo kontrafaktisk. Men det er ingen grund til at forkaste den. Tvartimod. For det kontrafaktiske har den tilfalles med stort set alt andet, vi tanker og siger. Sprog i sig selv er kontrafaktisk i den forstand at det ikke bygger reelle virkeligheder, men virtual realities op. Det er sprogets store force - og omme punkt - at det ikke afbilder virkeligheden, men opstiller en ny, eller rettere sagt mange nye.

Det er faktisk også Luhmanns pointe, som vi vil se om lidt. Hos Luhmann er det menneskets store force at vare sig bevidst at verden er kontingent tilfæaldig og mulig på andre måder (Luhmann 1987:47) - og det bunder lige precist $i$, at sproget faktisk ikke kan fange realiteten som den er. Det det til gengaeld kan, er at fange muligheder, virtual realities, der allesammen er kontrafaktiske, om det så er logne, planer, idealer, tolkninger, utopicr cller beskrivelser, for ikke at tale om ordre, bon og lign. De opstiller alle noget som i den form ikke findes i virkeligheden.

At sproget er sådan indrettet, ved vi i hvert fald siden Saussure. Saussure gor systematisk op med den naive dagligdags antagelse at et ord har en be- 
tydning, og det ordet betyder, er det derude i virkeligheden, som ordet henviser til. At et tre hedder tra fordi det er et tra. At sproget afspejler virkeligheden. At sprogets ord er en rakke etiketter, der er klistret på tingene som de findes ude i virkeligheden.

Saussure derimod siger: Sproget afspejler ikke virkeligheden, sproget former virkeligheden. Sproget er et system af tegn, og det enkelte tegns betydning fremkommer forst og fremmest ved forskellene til de andre tegns betydninger: En far er i en bestemt forbindelse en far, fordi han ikke kan kaldes mor, barn, søster, bror eller andet. Men betydningen fremkommer netop ikke ved en fast forbindelse mellem ord og virkelighed. For den virkelige far er netop til sit barns store forundring $i$ andre forbindelser også barn, bror eller andet, og kan måske også fungere som mor ellcr søster når alt andet glipper.

Sprogtegn er elementer i tegnsystemer, og deres betydning bestemmes forst $0 \mathrm{~g}$ fremmest af forskellene til de andre tegns betydninger. Som betydningssystemer dækker de forskellige sprog virkeligheden på hver sin måde, men afspejler den ikke bare (Saussure 1970).

Den psykologiske mekanisme bag denne tegnteori har Nørretranders beskrevet som talens tra (Norretranders 1991:148ff). Ideen om talens tra går ud på at man til at starte med siddér med en hel masse information i hovedet, som man har om noget man gerne vil udtrykke i ord. Den masse af information er ikke til at udtrykke i sprog, både fordi den er for stor i sin detail- og associationsrigdom, men også fordi den er for personlig, tilfæeldig og uordnet. Derfor skal der vælges fra, smides ud eller som Norretranders kalder det: produceres eksformation. Udsmidningen foregăr ikke tilfældigt. Det er ikke nogen planlas proces. Og det er ikkc kun en kvantitativ reduktion. Den ender med en sproglig formulering, som barer meget mindre information $\mathrm{og}$ som yderligere har ordnet denne information i monstre - og dermed yderligere reduceret informationen ved redundans og forudsigeligched.

Mønstret er kommet til. Monstret har ikke ligget i den kempebunke af uordnede informationer, man startede med i sit hovedet - bevidsthedssubstansen. Muligheden for monstret, for orden, er kommet med sproget. Som noget nyt og noget andet. Ikke som en afbildning af bunken, men som en bestemt mulighed at skare den, at se den, at forstå dem.
Den sproglige formulering overfores, starkt reduceret, men ordnet, nxsten som et fro, der bliver lagt $i$ den andens bevidsthed hvor det så skal spire og gro og udfolde en ny, men lignende detail- og associationsrigdom som den det har tabt på sin vej til ordet, under eksformationsprocessen.

Og hvad har så alt dette med etik at gore? Det at vi i sprogets verden ikke umiddelbart har med virkeligheden at gøre, men med mulige verdener som vi hele tiden bruger til at forandre virkeligheden med, betyder at virkeligheden ikke kan udgøre det faste holdepunkt, vi er tilbøjelige til at opfatte den som.

Virkeligheden bliver en social konstruktion. Vores adgang til virkeligheden er i så høj grad underlagt sproget, at virkeligheden derfor ikke kan fungere som nogen pålidelig målestok for sproglige fremstillinger. Men hvad så? Så har vi kun hinanden tilbage. For sprog bruger vi med hinanden og på hinanden. I sproget har vi vores fallesskab. $\mathrm{Og}$ hvis vi skal kunne måle sproglige fremstillinger op mod noget sã er det dette frellesskab. Så cr det eneste faste punkt i verden det, vi kan blive enige om.

Og det er så her, etikken kommer ind. For når det eneste kriterium bliver enighed og ikke virkelighed, să skal vi stole på hinanden. Og når vi skal kunne stolc på hinanden, så skal vi ogsă selv opfore os sådan, at den anden kan stole på os. Og det vil sige: anstandigt, etisk, sådan at han ved hvor han har os. Ellers tor hverken den anden i lengden stole pá os, eller - hvad der måske er endnu vaerre - vi tor stole på den anden. For sæet nu han gor lige som os - og hvorfor skulle han ikke det, når vi gør det?

Etik er $\mathrm{i}$ sidste ende gensidighed som grundnorm, som jeg tidligere har citeret Apel for. At opfore sig etisk betyder i denne sammenhang: sădan at det ikke forhindrer at vi vil kunne blive enige, dvs. at den anden frivilligt er med på det. Det etiske er at orientere udfoldelsen af sin egen frihed ved den andens frihed.

Besynderlig og paradoksalt nok er det således gensidigheden $\mathrm{i}$ at acceptere den andens frihed, der bliver det eneste faste holdepunkt. Og det er faktisk også Luhmanns pointe med det, han kalder dobbelt kontingens (Luhmann 1987:148ff).

En principiel accept af den andens frihed er således kernen i en sådan etik.

Den hedder også diskursetik. For dens normer for intcraktion og kommunikation kan kun etableres ved en diskurs - ved at man bliver enig om dem ud fra den ideale talesituations betingelser ( $\mathrm{Ha}$ bermas 1983:103). 
De værdier, der må havdes ud fra en sådan etik, er de kommunikative vardier: sandhed, vederhæftighed og rigtighed, som alle i sidste ende kun kan proves pă om der ved diskurs kan opnås enighed om deres opfyldelse.

\section{Biologi og psykologi}

Habermas pointe er at den etik lares sammen med sproget fordi den er et uundvarligt moment ved sproget, nemlig det som făr sproget til at fungere som kommunikationsmiddel. Etik er essensen i den ideelle talesituation. Den er altid forudsat năr folk snakker sammen. Den er det bxercnde fundament i den enighed, der gor at man overhovedet kan snakke sammen: at man vil snakke sammen og dvs. at man derfor agter at holde sig så nogenlunde til den gensidighed og verdieme om sandhed, xrlighed og rigtighed som gor det at tale sammen meningsfuldt. Når man larer sproget, laerer man også at handle forståelsesorienterct cller kommunikativt.

For det at lare sproget er samtidig en afgørende vigtig faktor i den dobbeltsidige proces ethvert barn skal igennem: socialisations-individuationsprocessen. For sproget er i følge sin natur som kommunikations- og erkendelsesredskab reciprokt orienteret mod det gensidige forhold - og derigennem ogsa refleksivt - orienteret mod selverkendelse.

Den engelske psykiater Laing viste i 60'erne hvordan bestemte former for samspil i en familie kunne fore til de tilstande, som man diagnosticerer som skitsofreni: folelsesmassig foramelse og uoverensstemmelse mellem tanker og følelser (Laing 1970:106).

Det typiske for disse former for samspil er at forxldrene udsætter deres born for hvad Laing kalder for mystifikationer. Et typisk eksempel er når de udsender to signaler samtidig, et verbalt og et non-verbalt, hvoraf det non-verbale udtrykker det modsatte af det verbale (irritation - glade) og dermed 'diskvalificerer' det verbale (samme 102). E1ler: at forældrene åbenlyst gør tegn til hinanden om hvordan de opfatter barnet, men når barnet siger noget om det, nagter at det er tilfaldet. Eller at de konstant fortaller barnet at det ikke foler, mener eller ved det, det selv tror, men noget de kan form talle det. Det, der sker med bamet er, at det bliver usikker på hvad det er det ser, hvordan det skal opfatte tilsyneladende klart markerede udsagn, hvad det selv mener osv. Det mister evnen til at kunne orientere sig-eller rettere: det far ikke rigtigt mulighed til at udvikle en sădan evne, cn stabil selvbevidsthed og et fundamentalt tillidsfuld forhold til sine nærmeste og dermed også til andre.

Oversætter vi det til Habermas kan vi sige at barnet her er udsat for en systematisk forvrænget kommunikation, en kommunikation som netop ikke er kommunikativ handlen, og at det derfor ikke udvikler det spontane kendskab til de verdier der regulerer sproglig kommunikation (sandhed, arlighed og rigtighed) og den spontane tillid til eller den naive tro på sproglig kommunikation som tillader $æ$ gte gensidighed og selvsikkerhed.

Uden det kan samspillet ikke fungere.

Det er et resultat af at sproget bruges 'uctisk', uden respekt for den andens frihed, ikke gensidigt.

Ogsa biologer har set denne forbindelse mellem sprog og gensidighed, fallesskab og dermed etik. 'Enhver menneskelig handling finder sted i sprog. Enhver handling i sprog frembringer en verden skabt med andre og i (en) handling af sameksistens ... Derfor har enhver menneskelig handling en etisk betydning. Dette bånd mellem mennesker er i den endelige analyse grundlaget for al etik, som en refleksion af andres legitime ret til at vare tilstede' (Maturana og Varela 1987:222).

Biologisk set betyder det for menneskets fylogenetiske udvikling - iffg. Maturana og Varcla - en selektion og, prioritering af de dispositioner, som ligger bag samarbejdsprincipperne og samarbejdsnormerne: 'kxerlighed, eller hvis vi foretrakker et mildere udtryk, accepten af den anden person ved siden af os selv i det daglige liv. Dette er det biologiske grundlag for alle sociale fanomener: uden karlighed, uden accept af andre, der lever ved siden af os selv, er der ingen social proces, og derfor ingen menneskelighed' (samme 223). Menneskets evolution har således lagt op til en 'etisk' indstilling. Det er i kraft af en sådan grundlaggende etisk indstilling, mennesket som art har overlevet og vundet frem. En ganske fascinerende og provokerende tanke. Hvor 'jungleloven' var den (ny-) liberalistiske social-darwinistiske grundmetafor - og dermed legitimation for en konsekvent egoisme - i forretningsanliggender, peger nu forende biologer på altruisme - en principiel orientering mod den anden og dermed et principielt etisk standpunkt - som en afgorende evolutionsgevinst for mennesket.

En sădan biologisk fundering af etikken falder godt i tråd med hvad der gang på gang păpeges som noget karakteristisk i forbindelse med etik: 
dens spontanitet. En 'spontan livsytring' kalder Logstrup således impulsen til etisk handlen (Løgstrup 1972). Og også Zygmunt Baumann understreger sterkt - netop i opposition til modernitetens gennemrationaliserede etik - at 'moralsk an svarlighed er den mest personlige og uafhendelige mennesket ejer, og den mest kostbare af de menneskelige rettigheder' (Bauman 1993:250). Vi kender den også fra den kristne tradition: Det gode skal ene og alene gøres for det godes skyld.

\section{Luhmanns systemteori}

Når man behandler etik, bliver tonen efterhånden mere og mere højtstemt, navnlig når man fordyber sig i de mere fundamentale lag. Der kan det vare ret så befriende at se sagen ud fra et helt andet perspektiv.

Luhmann er funktionalist. Han er interesseret i hvordan sociale systemer fungerer, og ikke i hvordan de bør fungere for at være mest retfærdige eller rimelige,

Moral og etik interesserer ham kun som funktionsmåder, som han tilmed er ret kritisk indstillet overfor (Kneer 1993:178ff).

Alligevel arbejder han med en differens - differensen af tillid og mistillid - som han tematiserer sådan at den kommer til at ligge meget tat op ad det, man ellers ville kalde for det etiske. Jeg opfatter derfor på mange måder hans gennemgang af tillid som et vagtigt bidrag til en etik. Det er i givet fald ganske vist en kynisk etik, fordi overvejelserne tilsyneladende kun er orienteret mod effektivitet, fordi tillid hele tiden bliver tankt sammen med dens modsatning mistillid, og fordi han sager at udvikle den hen imod systemtillid. Men centralt i disse betragtninger står det andet menneskes frihed - selv om den ikke tematiseres som norm og krav, men som kendsgerning og betingelse.

Under alle omstandigheder burde Luhmanns meget subtile analyse af tillid og karakteristikken af dens mekanismer hore til standardlæsning for PR-studerende.

Jeg vil indledningsvis kort gore rede for nogle trak af Luhmanns systemteori. For Luhmann er alle enheder og helheder systemer - mere eller mindre lukkede funktionssammenhange. Det galder ogsa mennesker og samfund.

Systemer har en omverden, som altid er mere kompleks end systemet selv og derfor for systemet i denne kompleksitet ufattelig. Men systemet skal fungere i denne sin omverden og skal derfor have gjort omverden til sin omverden som den kan forholde sig til. Systemet er altsă nodt til at reducere omverdenens kompleksitet til et niveau, hvor det kan tumle den. Jo simplere systemet er, jo mere skal det reducere omverdenens kompleksitet for at kunne tumle den. Og jo mere systemet skal reducere omverdenens kompleksitet, jo mere unuanceret bliver resultatet og jo mere unøjagtige bliver systemets aktioner og reaktioner i forhold til onverdenens 'egentlige' kompleksitet.

For overhovedet at kumne tumle omverdenens kompleksitet, skal systemet altså altid have mekanismer til at reducere den med. Og for at kumne tumle den mere adxkvat, skal det samtidig have mekanismer til at foroge sin egen kompleksitet med.

Det er meget vigtigt for systemer både at kunne forøge og formindske kompleksitet - eller som Luhmann tolker det: at kunne problematisere noget (at age kompleksiteten) og lose problemerne (at mindske kompleksiteten). Et system, der selv ved at verden cr mere kompleks end det kan se og opfatte det og som selv ved at verden er kontingent, tilfreldig i den måde den fremtrader for det på og fuld af andre muligheder, vil meget bedre kunne forøge og formindske kompleksitet (problematisere og lose problemer) end et system, der ikke ved det.

Mennesket cr et system, der ved det. Det ved at det, det kan se og fatte af verden, ikke er hele verdens kompleksitet. Det ved det fordi det i sin omverden kan opleve andre mennesker ikke bare som inventar, men som subjektive, bevidste jeg'er som oplever som det sely og er nødt til at vælge som det selv - men bare anderledes. Anderledes fordi det er andre jeg'er med andre livshistorier og andre perspektiver på verden. Og man kan se disse andre jeg'er opleve en selv som del af deres omverden, og man kommer således til at opleve sig selv.

For memnesket er verden salledes ikke bare kontingent, men dobbelt kontingent. Dobbelt tillatdig, dobbelt usikker. For mennesket har i sin omverden storrelser som ikke bare er lidt svare at placere, på samme măde som alt andet er lidt svart at placere. De placerer sig selv. De - andre jeg'er iagttager mennesket på en måde det ikke selv kan, og valger derefter sclv, hvordan de vil placere sig.

Det er det, der gor dem endnu mere uberegnelige end alt det andet.

I forhold til andre mennesker, andre jeg'er, der selv kan opfatte omverdenen kontingent og som i forhold til en selv er frie til at valge, kommer tilli- 
den ind i billedet. 'Tillid drejer sig om reduktion af kompleksitet, og specielt af den kompleksitet, som kommer ind $i$ verden på grund af det andet menneskes frihed' (Luhmann 1973:32). 'I den forstand er tillid en universel social kendsgerning" (Luhmann 1987:181). For det andet menneskes frihed kan man ikke se bort fra uden at det hævner sig. Det andet menneskes frihed er umiddelbart givet med den måde, det fungerer på. Og over for denne frihed kan man ikke sikre sig ved beshtningsteknikker der er baseret på rationale kalkyler. Kalkylen kommer principielt til kort. Man er altid nodt til at gå ud over bæredygtigheden i de informationer man har om den anden og vise tillid.

\section{Tillid}

Over for det andet menneskes frihed skal kalkylen derfor suppleres med tillid. Og Luhmann forstår altså tillid ikke som noget, der er udviklet deduktivt - det ville vare kalkylen. Den bygger snarere på induktion (Luhmann 1973:26), men minder i sidste ende nok mest om abduktion - 'den logisk mindst nødvendige, men til gengald den mest kreative resonnementstype' (Togeby 1993:356) der 'angiver at der er en mulighed for at konklusionen er korrekt" (samme 355). Et moment af rationalitet er der i tillid. Tillid skal ikke vare blind. Sa fungerer den heller ikke.

Det, der gor at tillid er effektiv i social interaktion, er at den anden er i samme situation som man selv - også hans situation er dobbelt kontingent; heller ikke den anden kan regne en ud; også den anden er henvist til tillid. $\mathrm{Og}$ det man gor når man spiller tillidsfuldt ud, er derfor ikke bare at grtte eller gamble, men at lagge op til en forhandling om situationen og vise at man som et udspil selv er parat til at stole på den anden. At vise tillid er i meget høj grad også en selvfremstilling. Og det er 'svart at skuffe vist tillid' (Luhmann 1987:181).

Men hvad er det, der rykker tillidsfuld handlen i narheden af etisk handlen? Det er for det forste det at tillidsfuld handlen helt fundamentalt er orienteret ved og respekterer den andens frihed og mulighed for valg. Det er en vasentlig komponent af etisk handlen $i$ hvert fald siden oplysningstiden: respekt for menneskets grundlaggende rettigheder, hvoraf den vigtigste er frihed.

For det andet er det kun tillid, hvis det vises ensidigt, af egen drift og uforbeholdent. Tillid kan hverken blive kravet eller foreskrevet normativt (samme 181), 'den skal gives som en gave og tages imod' (Luhmann 1973:42). Det er et pendant til etisk handlens uegennyttighed som f.eks. har en lang tradition $\mathrm{i}$ kristen etik, hvor den ene hånd ikke skal vide hvad den anden gør og hvor man skal tilbyde den anden kind når man bliver sláet.

Tillid er - i forlangelse af det - også ubegrundet og uberettiget (samme 26 og 86). Forst năr man med tilliden løber en risiko, er det ægte tillidsfuld handlen. Tillid er en 'alligevel-strategi' (Luhmann 1987:179). Den beror altid pa en afvisning af dens modsatning: mistilliden, og er således selv et eksistentielt valg: at valge at udlevere sig selv til den andens valg.

Det svarer godt til det etiske kravs ubetingethed. At handle etisk betyder netop ikke at handle som situationen kraver det og som det bedst kan betale sig. Det betyder at handle i overensstemmelse enten med sin intuitive viden om rigtigt og forkert (jvf. Løgstrups spontane livsytring) eller med et tilsvarende princip som man bevidst og overbevist har tilsluttet sig.

Dette sidste kraver en meget væsentlig ting af den, der viser tillid - hvis det skal regnes som tillid

nemlig det at han har noget at have det i, en kerne af identitet, en indre sikkerhed (Luhmam 1973:86), 'strukturelt ikke bundne ressourcer, som kan mobiliseres hvis tilliden bliver skuffet' (samme 88). Tillid har som grundlag en selvsikkerhed.

Det galder for den der viser tillid, men det gælder også for den der onsker at gøre sig fortjent til tillid. 'Grundlaget for al tillid er fremstillingen af ens eget selv som en social identitet, der bygger sig selv op i sociale interaktioner og korresponderer med omverden' (samme 68). Skal man kunne vises tillid, skal man have en identitet, og det vil hos Luhmann sige: 'en adfardskontinuitet' (samme 67) - hverken stift, eller opportunistisk - som kan danne grundlag for forventninger. For 'al selvfremstilling forpligter - alene ved at den fremstiller et selv, som skal vare identisk med sig selv. Man skal, vil man forblive den samme, forblive således som man har fremstillet sig selv' (samme 69). Kynismens etik.

Goffman stăr lige bagved (og Luhmann henviscr da også ofte til ham). Men også her en klar parallel til etikken - i dette tilfelde middelalderens og navnlig barokkens etik, hvor en af hoveddyderne var constantia, det at forblive sig selv, bevare sin identitet. Hos Luhmann typisk koblet med et dynamisk aspekt: en flydende identitet, der i en vis forstand netop ikke forbliver sig selv, men konstant arbejder med sig selv og udvikler sig. 
For mig ligger det, der her fremtrader som en funktionel beskrivelse af den sociale mekanisme tillid, snublende nær en etik hvis grundlaggende vardier er: frihed og identitet eller selvbevidsthed, og hvis grundlaggende mekanisme er det frivilligt, ensidigt og uforbeholdent at turde udsatte sig for den andens frihed.

Det er en kynisk etik - på samme måde kynisk som Goffman er kyniker ved kun at beskeftige sig med masker eller faces. Heller ikke hos Luhmann er identitet andet end sammenhængende selvfremstilling og tillid ikke andet end det at vise tillid el. ler at vise at man modtager tilliden.

Det er kun overfladen, og ikke - som det plejer at være i etikken - netop det bagved overfladen. Men da der hos begge ikke er andet end overfladen, bliver overfladen det afgorende vigtige. $O g$ her har kynikeren måske ret? For det vigtigste er måske ikke at den andens frihed $\mathrm{i}$ virkeligheden bliver respekteret, men at man viser at man respekterer den ved reelt at respektere den - af hvilken grund det end mătte vare. Og det vigtigste er måske ikke om man i virkeligheden har en identitet, men at man gor sig umage for at vise en identitet ved at praktisere den.

Som topmålet af kynismen havder og häber både Goffman og Luhmann, at det at synes og det at være i sidste ende (måske) falder sammen:

I tillidsfulde forhold er der ind bygget et moment af social kontrol. Tillid hober sig op som en slags kapital, der abbner muligheder for mere vidtrakkende handlinger, men som ogsă løbende skal bruges og plejes og som fastholder brugeren i en tillidsvakkende selvfremstilling, som han kun vanskeligt kan komme vek fra. Man kan erhverve tillid ved at snyde med sin selvfremstilling, men man kun kun bevare tilliden og bruge den som kapital man lobende har rådighed over, hvis man fortswtter med at snyde. Så forvandler skinnet sig umarkeligt til virkelighed, de foregøglede kvaliteter bliver til en vane. Tillidens fordele forpligter. Tillid opdrager.

(samme 71).

Vi er således tilbage ved den retoriske appelform ethos, appel via selvfremstilling, som er karakteristisk for PR fremfor logos og pathos. PR er selvfremstillingens kunst - en selvfremstilling der både skal skabe tillid og derfor må vise tillid. En selvfremstilling, der derfor forst og fremmest både skal respektere den andens frihed og som skal vare udtryk for egen kontinuitet og identitet, og som skal forene dissc to ting til en dynamisk helhed.

I modsætning til hvad man skulle tro, să bliver tillid, og dermed det at skabe tillid og vise tillid og dermed PR - vigtigere og vigtigere jo mere differentieret og gennemrationaliseret samfundet bliver. Jo mere man planlegger, jo flere operationer man kader sammen, jo flere mennesker der bliver involveret, jo flere usikkerhedsmomenter bliver der og jo mere vil man have brug for tillid 'for at kunne bxre fremtidens teknisk frembragte kompleksitet' (samme 17).

\section{Regnskabet gores op}

Etik cr ikke bare noget, filosofferne efter en rimelig lang pause har taget op igen. Det er ikke noget, velmenende mennesker nu ogsã vil indfore i okonomien. Det akonomiske liv er i dag mere end nogensinde for afhengigt af den 'menneskelige faktor'. Specielt i vakstomrader som servicevirksomheder og vidensbaseredc virksomheder spiller den en storre og storre rolle. Her er viden, intuition og kreativitet, evne til social kontakt og indfoling efterspurgte ressourcer og kvaliteter, som ikke kan objektiveres og ikke kan efterlignes, og som derfor giver enkeltindividet en nogleposition.

Problemet med den menneskelige faktor - set ud fra virksomhedens eller organisationens perspektiv - er at den ikke kan styres. Den skal styre sig selv.

Det er i denne forbindelse etik er vigtig. For etik er et redskab til selvstyring. Det er et meget elementart redskab. Mennesket synes biologisk-evolutionart at vare disponeret for det (Maturana) Varela). Og sproget - det medium som har afgom rende betydning for at menneskelige samfund kan fungere - har det indbygget som en universel forudsatning for kommunikation (Habermas).

Den menneskelige faktor synes forst og fremmest at vare karakteriseret ved en form for helhed cller syntese hvor smuk, rigtig og godt falder sammen (Baumann) og sandhed, vederhæftighed og rigtighed går op i en hojere enhed (Habermas). Det er en syntese båret af en dyb og uproblematisk selvsikkerhed der grunder sig på en lige så dyb og uproblematisk sikkerhed og fortrolighed med den verden og de sociale sammenhxnge man er vokset ind i, ens livsverden (Luhmann, Habermas). Livsverden cr kun en term for det. Andre termer er livsform og kultur. 
Når livsverdenen og dermed den uproblematiske sikkerhed er truet og helheden splittes op, synes mennesket at miste sin orientering og sin evne til selvstyring (Laing, Habermas). Og netop det synes at være tilfaldet i det moderne samfund hvor man taler om fragmentering (Baumann), differentiering (Luhmann) og en polarisering af livsverden og systemverden med sociale patologier til folge(Habermas).

Deter diagnosen, som nogle (Baumann, Habermas) er meget merc foruroliget over end andre (Luhmann). Og det er i denne forbindelse den etiske genoprustning der er i gang, skal ses. Men det er også i demne forbindelse, refleksionerne over etik bliver relevante hvis ikke etik-bølgen skal ende som et stort blålys.

Der er nogle betingelser, der skal vare opfyldt for at man kan tale om etik. Den forste betingelse er det andet menneskes frihed. Etisk opforsel er altruistisk for savvidt som den respekterer den andens frihed $o g$ ger den til en forudsxtning for ens egen handling. Det ligger băde i Luhmanns tillidsbe. greb og Habermas' diskursbegreb. Den anden skal altid kunne problematisere om man overholder gyldighedskravn, som stilles til kommunikativ handlen, og man er altid forpligtet til at indfri dem. Og tillid er netop at underlagge sig det andet menneskes fri vilje. Uforbeholdent at udsatte sig for en andens frihed.

Den anden betingelse er ens egen ansvarlighed. Etisk opforsel er nok orienteret mod den andens frihed, men derved ikke dikteret af den anden. Etisk opforsel er tværtimod grundet på ens egen indre overbevisning. Man handler under eget ansvar. Man skal ikke lade sig styre af den anden. Det eneste man skal lade sig styre af er ikke at krenke den andens frihed. Bade diskurs og tillid forudsetter, at man selv har en indre sikkerhed og overbevisning. Det ville vare absurd at gå ind i cn diskurs om ting man ikke vil forsvare, eller at tage tillidens risiko på sig hvis man ikke selv havde et projekt man forfulgte. Det betyder dog ikke at man ikke kan rokke sig vak fra sin overbevisning. Både Habermas' diskursbegreb og Luhmanns identitetsbegreb er netop lagt an pä forandringer, justcringer og udvikling og netop ikke på uforanderlighed. Men selv om der lagges op til forandringen udefra, skal den - hvis den skal vare agte-komme indefra, skal ske med overbevisningens indre sikkerhed som man kun selv kan stå inde for. Ved at fokusere på etikken i kommunikationen, fokuserer man på afsenderen. Hvor man ved at fokusere på informa- tionen, fokuserer på sagen, og ved at fokusere på effektiviteten, fokuserer på modtageren. Etiske regnskaber

Begge etikkens hovedmomenter - at respektere den andens frihed (selvkritik og selvbegransning) og at påtage sig sit egen ansvar (sclvbevidsthed) er vasentlige momenter både for diskurs og for tillid, og begge skal laeres og skal forst og fremmest have plads til at kunne udfolde sig.

I denne forbindelse ser etiske regnskaber (Pruzan og Thyssen 1989:188) - ogsả som et vesentligt moment i dialogisk PR - meget lovende ud. Etiske regnskaber skal - i modsatning til økonomiske koncentrere sig om værdier som åbenhed, tolerance, udvikling, tryghed, trivsel og kvalitet. Det der săledes skal gøres op, er graden af livskvalitet, som institutionen kan byde sine nagleinteressenter, typisk de ansatte, samarbejdspartnerne og lokalsamfundet.

Etiske er disse regnskaber af to grunde: For det forste på grund af indholdet i regnskaberne, på grund af verdikoden. De verdier, der her er tale om, kan antydes med begreber som den menneskelige faktor', 'tilfredshed', 'livskvalitet'og 'integration' (Meyer 1993:12). De er etiske forsåvidt som de er orienteret mod de andres - de afhangiges, de ansattes, patienternes, $\mathrm{i}$ det hele taget brugernes behov og interesser.

For det andet er de etiske på grund af fremgangsmåden ved at opstille dem. Det er interessenterne selv, der diskuterer sig frem til hvilke vaerdier de vil tillagge betydning. Det er interessenterne, der far lov og frihed til at opridse de præmisser systemet skal vurderes på, og de gor det ikke ved at trumfe deres synspunkter igennem, men ved igennem diskussioner at blive enige om dem og forpligte sig pă dem.

Det er navnlig denne fremgangsmåde, der for alvor er etisk relevant. Og den kaldes da også for en 'etisk lareproces' - en lareproces institutionen og dens interessenter ingár i og 'som går ud på at skabe viden om og forståelse for organisationens indre liv og dens samspil med omverden' (samme 5). Lereprocessen er etisk lige pracis fordi den som ger at udnytte sproglig kommunikations implicitte etiske potcntiale som Habermas peger på, til at opnå en gensidig forståelse eller konsensus, baseret pâ tillid mellem de implicerede parter (samme 3).

Og som sădan, som denne lereproces, vil etisk regnskab og bredere dialogisk PR kunne opnå det, som man anses for at vare den vasentligste effekt: at sensibilisere folk - gore dem folsomme - for 
etik - at satte dem i stand til at forstå både deres egne og andres legitime interesser og at afveje og forlige dem med hinanden. Dvs. etablere gensidighed og tillid.

\section{Gensidighed som grundnorm}

Etik er gensidighed som grundnorm. Gensidighed har altid varet menneskets udviklingshistoriske niche. Mennesket har altid - som art - overlevet $\mathrm{i}$ kraft af gensidighed, dvs. etik.

Med etiske regniskaber og dialogisk PR er den for alvor blevet opdaget som ressource også i den okonomiske sfare og skal bruges bevidst. Og lur mig om den ikke også misbruges - sâdan som udgiverne til Mediekultur 20 også antyder det i deres konstatering af at der er 'mange muligheder for at slå plat på etikken' (3).

Men gensidighed og tillid er noget uhyre vanskeligt noget at have at gore med. Man kan godt snyde med etik, for mennesket er jo netop nærmest biologisk programmeret til gensidighed, er tillidsfuldt. $\mathrm{Og}$ tilliden kan endda tåle skuffelser. Den skal kunne tåle skuffelser. Det kvalificerer den forst som tillid (Luhmann). Men den slides tynd ved skuffelser. $O g$ når forst mistilliden er vakt, så skal der efterhånden kun meget lidt, rent logisk set urimeligt lidt, til at vælte det hele og ødelægge tillidsforholdet og gensidigheden eftertrykkeligt (Luhmann).

Dertil kommer at iagttageren altid iffg. Goffman har et forspring for den agerende. Det er nemmere at iagttage selvmodsigelser i en andens opforsel, end at undgå dem i ens egen opforsel (Goffman 1992:17). Og det betyder at den der handler som han mener det cr rigtigt - dvs. ikke snyder har et forspring for den der ikke gor det (Luhmann 1973:92). Og det igen betyder at den der handler ctisk og beslutter sig for at mene at det er det rigtige, også har et forspring. Det er det, jeg tidligere har kaldt 'kynismens etik', og som nok ikke er det varste man har.

Man kan altså nok snyde med etik og gensidighed, men nappe i det lange lob. Og netop de afhangige har som iagttagere en meget fin sans for det agte og det urgte, og det vil kynisk-etisk sige: det gennemforte og det ikke-gennemforte.

Godt nok er den idcelle talesituation kontrafaktisk, men mistillid som grundstemning er kontraproduktiv. Derfor etik og dialog.

\section{Litteratur}

Apel, Karl-Otto 1984. Geschichtiche Phasen der Herausforderung der praktischen Vernumf. I: Apel, Karl-Otto m.f. (ed) Praktische Philosophie/Ethik: Dialoge 1, s. $70-89$. Frankfurt/M. Fischer Taschenbuch Verlag.

Bateson, Gregory 1972. Steps to an Ecology of Mind. San Francisco: Chandler Publ. Comp.

Bauman, Zygmunt 1993. Postmodern Ethics. Oxford and Cambridge: Blackwell Publ.

Blach, Thomas og Jesper Hojberg 1989. Handbog information og public relations. Kobenhavn: Borgens Form lag.

Brown, Penelope and Stephen C. Levinson 1978. Politeness. Some universals in language usage. Cambridge: Cambridge University Press.

Callahan, Joan C. (ed) 1988. Ethical Issues in Professional Life. New York, Oxford: Oxford University Press.

Drucker, Peter 1989. Virkeligheden er blevet en anden. Kobenhavn: J.H. Schultz Information.

Fairclough, Norman 1994. Discourse and Social Change. Cambridge: Blackwell Publ.

Giddens, Anthony 1994. Modernitetens konsekvenser. Kobenhavn: Hans Reitzels Forlag.

Goffman, Erving 1992. Vart rollespill til daglig. Larvik: Pax Forlag.

Habermas, Jürgen 1962 . Strukturwandel der Offentlichkeit. Neuwicd und Berlin: Luchterhand Verlag.

Habermas, Jürgen 1971a. Theorie der Gesellschaft oder Sozialtechnologie? I: Habermas, Jürgen und Niklas Luhmam. Theorie der Gesellschaft oder Sozialtechnologie. S. 142-290. Trankfurt/M.: Suhrkamp.

Habermas, Jügen 1971b. Verbereitende Bemerkungen zu ciner Theorie der kommunikativen Kompetenz. I: Habermas, Jügen und Nklas Luhmamn. Theorie der Gesellschaft oder Sozialtechnologic. S. 101-141. Frankfurt/M.: Suhrkamp.

Habermas, Jügen 1980. Konventionelle oder kommunikative Ethik? I: Apel, Karl-Otto m.fl. Praktische Philosophie/Ethk. Reader zum Funk-Kolleg 1, s, 32-45. Frankfurt/M. Fischer Taschenbuch Verlatg.

Habermas, Jurgen 1981. Theorie des kommunikativen Handelns. Bd. I og II. Frankfurt/M.: Suhrkamp.

Habermas, Jürgen 1983. Moralbewusstsein und kommum nikatives Handeln. Frankfurv/M.: Suhkamp.

Hansen, Nils Gunder 1992. Etik i 90'ene. Kobenhavn: Nordisk Forlag A.S.

Jorgensen, Charlotte og Merete Onsberg 1987. Praktisk argumentation. Kobenhavn: Teknisk Forlag.

Kjoller, Klaus 1980 Gode Grunde? Introduktion til ar. gumentationsanalyse. Kobenhavn: Gjellerup.

Kneer, Georg og Armin Nassehi 1993. Niklas Luhmanns Theoric sozialer Systeme. Eine Einführung. München: W. Fink Verlag.

Laing, R.D. and A. Esterson 1970. Sanity, Madness and the Family. Middlesex: Penguin Books Ltd.

Lausberg, Heinrich 1960. Handbuch der literarschen Rhetorik. München: Max Hueber Verlag.

Luhmann, Niklas 1971. Systemtheoretische Argumenta- 
tionen. Eine Entgegnung auf Jürgen Habermas. I: Habermas, Jürgen und Niklas Luhmann. Theorie der Gesellschaft oder Sozialtechnologie. S. 291-404. Frankfurt/M.: Suhrkamp.

Luhmann, Niklas 1973. Vertrauen. Ein Mechanismus der Reduktion sozialer Komplexitt. Stuttgart: Ferdinand Enke Verlag.

Luhmann, Niklas 1987. Soziale Systeme. Frankfurt/M.: Suhrkamp.

Logstrup, K.E. 1972. Norm og spontaneitet. København: Nordisk Forlag A.S.

Maturana, Humberto og Francisco Varela 1987. Kundskabens trw. Den menneskelige erkendelses biologi ske rodder. Arhus: ASK.

Meyer, Thorbjørn 1993. Det Etiske Regnskab 1992. Centralsygehuset i Nastved.

Morsing, Mette 1991. Den etiske praksis. En introduktion til det etiske regnskab. Kobenhavn: Handelshoj]skolens Forlag, Nyt Nordisk Forlag.

Nielsen, Henrik Kaare 1991. Demokrati i bevagelse. Arhus: Arhus University Press.
Næess, Arne 1967. Filosofiens historie I-III. Kobenhavn: Vintens Forlag A/S.

Norretranders; Tor 1991. Mærk Verden. En beretning om bevidsthed. Viborg: Gyldendal.

Pruzan, Peter og Ole Thyssen 1989. I: Hildebrandt, Steen (red) 1989. Helhedssyn og ledelse ...monatik til et monster. Hinnerup: Ankerhus Gruppen, Instituttet for Socialøkologi.

Reese-Schäfer, Walter 1994. Jürgen Habermas. Frankfurt/M./New York: Campus Verlag.

Saussure, Ferdinand de 1970. Lingvistikkens objekt. I: Madsen, Peter (udg.) Strukturalisme. En antologi. Kobenhavn: Rhodos.

Schütz, Alfred und Thomas Luckmann 1979. Strukturen der Lebenswelt. Frankfurt/Main: Suhrkamp Verlag.

Togeby, Ole 1993. Praxt. Pragmatisk tekstteori 1-2. Arhus: Arhus Universitetsforlag.

Uwe Geist er lektor ved Institut for Sprog og Kultur, RUC. 


\title{
Anti-essentialisme og receptionsforskning
}

\section{Et forsvar for teksten}

\section{Af Arild Fetveit}

\begin{abstract}
Hvad var ärsagen til, at receptionsforskningen i 1980 erne kunne opnå en så omfattende popularitet inden for medieforskningen? Arild Fetveit argumenterer i artiklen for, at receptionsforskningens succes bunder $i$, at den var $i$ stand til at indkorporere tidens starke anti-essentialistiske stromninger inden for human-ag samfundsvidensk aberne. Han argumenterer endvidere for, at et opgør med de relativistiske tendenser pa feltet kraver en normere droftelse af de teoretiske problemer, som anti-essentialismen har bragt med sig. Han päbegynder hermed et teoretisk opgor med hvad han ser som overvurderingen af leserens frihed og undermineringen af tekstbegrebet. Artiklen trokker på teoretikere som Kant, Heidegger, Gadamer, Rorty, Eco og Fish, og diskuterer de positioner inden for medieforskningen, som er blevet fremfort af Morley, Fiske, Bruhn Jensen og Schroder. Ved at gå Fish og Rorty på klingen når Arild Fetveit frem til den overraskende pointe, at de anti-essentialistiske, konstruktivistiske positioner i virkeligheden er facade for en mere metafysisk tekstopfattelse.
\end{abstract}

"... a text is only a pronic where the author bring the words and the readers bring the sensew (Todorov).

Resepsionsstudiene var uten tvil 80-tallets storste motebelge innenfor medievitenskapen. De har utvilsomt gitt oss verdifull kunnskap om hvordan ulike mennesker opplever fjernsynsprogrammer. Men det har ikke bare vart bcgeistring; diverse kritiske røster har hevet stemmen mot tendenser til relativisme og overvurdering av leserens frihet. Selv om ytterliggående posisjoner har blitt mindre populare, betyr ikke det at de teoretiske problemer som ligger til grunn for de relativistiske tendensene cr droftet til bunns. Tvert imot, jeg synes det er vesentlige tema som ikke er belyst på dette feltet, og jeg har derfor satt meg fore å kaste lys over i alle fall ett av dem: sammenhengen mellom antiessensialismen og fremveksten av resepsjonsforskningen.

Jeg vil forsoke å vise hvordan kritikken av metafysikken har kommet til à bli oppfattet som en trussel mot teksten som autonomt studieobjekt. Ikke bare har den truet teksten - helt siden Kant har den truet verden. Med denne parallellen onsker jeg å antyde et slektskap mellom leserorienterte tekstteorier og konstruktivistiske retninger innenfor epistemologien. Vi har på begge felter kumnet se en tendens til a foretrekke subjekt-sentrerte framfor objekt-sentrerte beskrivelser; verden og teksten blir ikke lenger oppfattet som objektivt gitte storrelser, men som produkt av subjektets beskrivelsesstratcgier. Derfor vinner konstruktivistiske retninger frem innenfor epistemologien og lesersentrerte retninger innenfor tekstteori. Enkelte har gătt sả langt som til ả erklare baide tekst og verden som ikke-eksisterende. Dermed har det beskrivende subjekt nærmest blitt stående alene igjen på arenaen. Dette har ledet til overvurderinger av subjektets frihet til a konstruere verden og a lese tekster etter eget forgodtbefinnende.

Den radikale undermineringen av tekstbegrepets legitimitet har fätt naring fra en misforstätt antiessensialisme. $P_{a}^{\circ}$ sett og vis er både ytterliggående resepsjonsteori og konstruktivisme barn av en metafysikk pă defensiven. Og jeg sier på defensiven', for năr den siste rest av den metafysiske essensialismen faller, vil også teksten og verden, sammen med en rekke andre storrelser som er blitt erklert ikke-eksisterende, gjennoppstä fra asken. 